\title{
Implication of Hawālah in Islamic Finance Practice
}

\author{
Al Khansa Sulaiman Dawood Al Raisi, Imelda Rodriguez, \\ Miras Tustikbayev, Nazerke Omarova, Waleeda Abdul \\ Rahman, Aishath Muneeza
}

International Center for Education in Islamic Finance (INCEIF), The Global University of Islamic Finance, Malaysia

\begin{abstract}
:
This article aims at examining the concept of hawālah and its contemporary applications in banking sector. For this purpose, the authors examine the conceptual and literal meaning of hawālah and scrutinise its applications in two Malaysian banks. While Bank $\mathrm{A}$ is a dual bank which offers both conventional and Islamic banking, Bank B is a full-fledged Islamic bank. Results indicated that there is a general lack of awareness about the concept of hawālah used by both banks. Although there is strong awareness of Islamic Shariah's strong prohibition on taking interest, the staff members are uninformed about the underlying concepts of hawālah. In addition, the authors found that the hawālah-based services offered by both banks were not significantly different from conventional banks' products and services. It is recommended that further research can be conducted to find out the reluctance among the Islamic banks to name remittance system by using the term hawālah.
\end{abstract}

Paper type: Research paper

Keywords: Shariah, Funds Transfer, Hawālah, Islamic Finance, Islamic Banking, Remittance 


\section{Introduction}

In Arabic term, ḥawālah means "change" or "transfer" (Wilson, 2002: 2). The Accounting and Auditing Organization for Islamic Financial Institutions (AAOIFI) (2010) defines Al- Hawālah as a transfer of a debt from the transferor to the payer. In fiqh muamalat, hawālah refers to the transfer of financial liability from one debtor to another that would free the initial debtor from any debt (Kureshi and Hayat, 2014). The Hanafi's define hawālah legally as a transfer of liability for a debt from the debtor to the person whose name appears in the contract as being liable for the debt (AlZuhayli, 2003). Further, the principle of hawālah can be found in Article 673 of the Mejelle which describes it as a "transfer from one debtor account to the debtor account of another" (Kureshi and Hayat, 2014: 153).

There are various modern use of hawālah, including bills of exchange and issuance of cheques (Kureshi and Hayat, 2014). One of the common applications of hawālah system is remittance where migrant workers remit money to their family or relatives in their home country (El Qorchi et al., 2003). Arguably however, the efficiency and anonymity provided by hawālah also makes it a system that could be used for money laundering (Jost and Sandhu, 2000; Nelson, 2009; Wilson, 2002) and crime financing (El Qorchi et al., 2003). The misuse of hawala in fund transfer have attracted growing interest (e.g. El Qorchi et al., 2003; Passas, 1999; van de Bunt, 2008), but the legitimate use of hawālah in the banking sector has received comparatively less attention.

Therefore, the aim of this paper is to shed some light on the principle of hawālah and its modern applications in banking sector. In this study, Malaysia was chosen due to its regulated and sophisticated Islamic finance marketplace. The focus on the area of personal finance was mainly because of the prevalence of use and though the preponderance may be on money remittance and cheque clearing; travellers' cheques was included as it had characteristics of both of these uses. These areas are explored in terms of their Sharī'ah compliance, their uses and importance. Emphasis will be given to the application of hawālah as a money remittance system because of its use in both formal and informal funds transfer systems.

In this study, we will use AAOIFI's definition of hawālah as a transfer of a debt liability from the transferor to the payer when we look at the validity of the transactions studied from a Sharī' $a$ ah perspective. In discussing remittance specifically, however, we will also use the term hawālah to refer to the money transfer mechanism in the informal sector.

\section{Literature Review}

The practice of transferring debt can be traced back in Roman times (Niazi, 1991). To facilitate and promote trade between distant regions, merchants or entrepreneurs have to come up with an effective and reliable remittance system. According to El Qorchi et al. (2003), the remittance system deeply rooted at a time when banking instruments were either inefficient or absent.

International Journal of Management and Applied Research, 2016, Vol. 3, No. 3 
The translation from Arabic to English can often result in words with the same meaning being spelled differently. This is the case when it comes to hawālah (AlZuhayli 2003), which may be written as hawala (Maimbo, 2003), hawalah (Haqqi, 2011) and hiwalah (International Shari'ah Research Academy for Islamic Finance, 2012). Interestingly, some scholars (El Qorchi et al., 2003; Passas, 1999; van de Bunt, 2008) refer hawālah as an Informal Value-Transfer System (IVTS). Viles (2008) argues that it is not just money that is transferred in hawālah, it is anything of value. Maimbo (2003) states that hawālah "refers broadly to money transfer mechanisms that exist in the absence of or parallel to, conventional banking channels" (page. v). Other studies such as Viles (2008) and Jost and Sandhu (2000) simply use the term to refer to alternative remittance systems.

According to International Sharī'ah Research Academy for Islamic Finance (ISRA) (2010), there are five pillars of hawālah: the Transferor, Transferee, Payer, Debt, as well as the Offer and Acceptance. While the Transferor refers to the person who was the original debtor, the Transferee refers to the creditor and the person who consents to receive payment through the debtor of the transferor. Next, the Payer refers to the party accepting the liability that will be collected by the transferee, whereas the Debt refers to the subject of the transfer.

The legitimacy of the hawālah contract is based from the Qur'an, the Sunnah, Ijma' and reasoning as established by AAOIFI in its basis for the Sharī'ah ruling. However, the conditions of hawālah differ among and between Sharī'ah schools, namely Hanbali, Mālikīs' and Shafi 'i. More specifically, the juristic views differ with regards to the consent of parties, liabilities involved and on termination of the contract (AlZuhayli, 2003). Table 1 illustrates differences of opinions in four major Fiqh school in regard with consent, liability and termination.

Table 1: Differentiation of Ḥawālah conditions by Sharī‘ah Schools

\begin{tabular}{|c|c|c|c|}
\hline Conditions & Hanafīs & Shafi‘i \& Mālikī & Hanbali \\
\hline Consenting Parties & $\begin{array}{l}\text { Only the consent of } \\
\text { the transferee and the } \\
\text { payer are necessary. }\end{array}$ & $\begin{array}{l}\text { Only the consent of } \\
\text { the transferor and the } \\
\text { payer are necessary. }\end{array}$ & $\begin{array}{l}\text { Only the consent of } \\
\text { the transferor is } \\
\text { necessary. Sufficient } \\
\text { for payer and } \\
\text { transferee to be } \\
\text { informed. }\end{array}$ \\
\hline $\begin{array}{l}\text { Extinguishing } \\
\text { liability of the } \\
\text { transferor }\end{array}$ & $\begin{array}{l}\text { The transfer of debt } \\
\text { does not result in } \\
\text { absolution for the } \\
\text { transferor, whose } \\
\text { liability for the debt } \\
\text { remains intact as } \\
\text { before. }\end{array}$ & $\begin{array}{l}\text { If the transfer of debt } \\
\text { is concluded, and the } \\
\text { creditor consents to } \\
\text { the transfer of } \\
\text { liabilities, he no } \\
\text { longer has a right to } \\
\text { demand repayment } \\
\text { from the transferor } \\
\text { under any } \\
\text { circumstances, } \\
\text { whether or not it is } \\
\text { possible to collect } \\
\text { from the transferee. }\end{array}$ & $\begin{array}{l}\text { If the creditor } \\
\text { stipulates a condition } \\
\text { that transferee must } \\
\text { be in good position, } \\
\text { and then discovers } \\
\text { that he is facing } \\
\text { financial difficulties, } \\
\text { he may again seek } \\
\text { repayment from } \\
\text { principal debtor. }\end{array}$ \\
\hline
\end{tabular}

International Journal of Management and Applied Research, 2016, Vol. 3, No. 3 
Termination of Contract

Upon mutual agreement, settlement of the debt, death of the payer where the transferee inherits his property or upon absolution by the transferee through hibah or charity

There are two types of hawālah: the restricted and the unrestricted model. Diagram 1 illustrates the restricted model, where the payer owes a sum of money to the transferor and the transferor owes a debt to the transferee. The transferor can elect to transfer the payer's debts to the transferee in order to settle the debt.

Diagram 1: Restricted Type of Ḥawālah

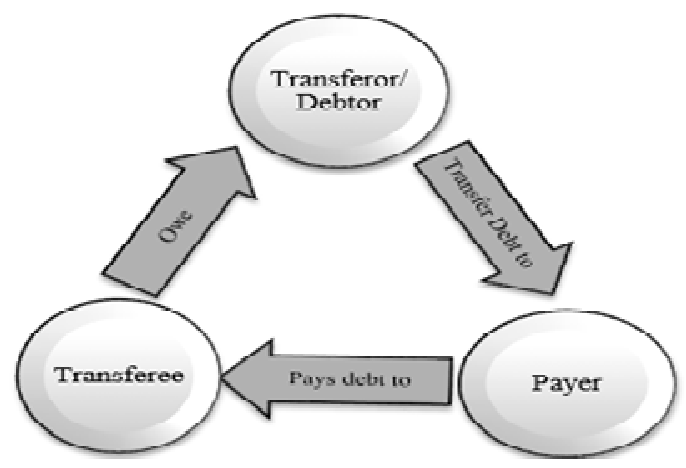

Diagram 2 illustrates the unrestricted model, where the payer need not owe money to the transferor yet the payer may still undertake to pay the transferor's debt from his own funds provided that this directive came from the transferor.

Diagram 2: Unrestricted Type of Ḥawālah



In the modern financial era, the principle of hawālah is commonly used in both formal and informal financial systems. As indicated by Kureshi and Hayat (2014), the concept of hawālah has been widely adopted in contemporary banking services, namely: bill of exchange, promissory note, cheques, remittance and bank draft. It is also a mechanism which can be used to settle international accounts by book transfer.

International Journal of Management and Applied Research, 2016, Vol. 3, No. 3 
By its very nature, hawālah is just a fund transfer from one party to another. There are various hawālah-based transactions have been made in an absence of a formal financial institution such as bank or money exchange, and such transaction is commonly known as 'informal funds transfer' (El Qorchi et al., 2003; Jost and Sandhu, 2000; Wilson, 2002). According to Wilson (2002), there are two common aspects of informal hawālah-based transactions: first, hawālah transactions can be conducted both domestically and internationally, including remote parts of the world; second, a hawālah transaction usually involves 'principle' and 'intermediary'. What happens in the international transfer is that a person from Country A wishing to send money to a person living in Country $\mathrm{B}$, and the remitter can to a financial intermediary in country A. This intermediary instructs his contact in country B to deliver the sum of money to the recipient who should be in possession of a code which is used to validate that he is indeed the intended recipient. This transaction is subject to a fee. Though slips of paper might be provided, words and mutual trust are the important elements of the contract. Nevertheless, as per (Maimbo, 2003), hawālah is also used due to the absence of or in parallel to the formal banking sector such as in Afghanistan.

Maimbo presents an in-depth study of the hawālah system in Afghanistan in his 2003 research where he verified that hawaldars or the money exchange dealers in Afghanistan, who operate primarily in open-air markets provide convenient, safe, reliable and inexpensive means of transferring funds both domestic and international. At the time of the study, there was no real formal banking system thus even the international aid institutions and non-government organizations (NGOs) use the ḥawālah system to disburse development funds.

A significant volume of transactions and a driving force in the continued growth of these alternative remittance systems is attributable though to the large migrant workers populations who remit money to their family and relatives in the home country (Shehu, 2004; Hernandez-Coss and Bun, 2007; Siegel et al., 2010). Many migrant workers consider the hawala systems as more reliable, inexpensive, and efficient, compared to wire transfer services offered by financial institutions (Shanmugan, 2005; van de Bunt, 2008; Viles 2008; Wilson, 2002).

In short, the socio-economic perspective of hawālah indicates that it is a rational economic choice for remitters in many countries, especially where banking system is weak or absent.

\section{Methodology}

This paper has a specific focus on personal finance, and thus other modern applications of hawālah in the international finance and trade are not examined. This is an exploratory study which based on both primary and secondary sources. A series of face-to-face interviews were conducted with staff from two Malaysian banks: a dual bank with both conventional and Islamic operations and a solely Islamic bank. The dual bank (Bank A) was chosen because it is the largest local bank in terms of asset size in both the conventional and Islamic space. The solely Islamic bank (Bank B) was chosen because of its status as a full- fledged Islamic bank. The interviews were followed up by a number of phone calls to their customer service centres as well as

International Journal of Management and Applied Research, 2016, Vol. 3, No. 3 
information available on their web sites. Secondary sources such as articles, journals and books were also used particularly in the study of hawālah as a remittance system.

\section{Discussion: Practical Application of Ḥawālah Through Experience}

The scope of this study is limited to the applications in the area of personal finance. This area was chosen because the services to be studied are commonplace and generally accepted as being Sharī'ah compliant yet the underlying Sharī'ah principle seems to be unknown.

The following section will address the previously selected financial instruments, how it is practiced in Malaysian banks and what are the documents required.

\subsection{Remittance}

Remittance in simple term is an international electronic transfer of funds used by the financial institutions. Due to the importance of the electronic transfer, the US government agency had formed Consumer Financial Protection Bureau (CFPB) (2014) had issued 12 CFR Part 1005, Regulation E in respect to electronic fund transfer and remittances services from the financial institutions. The main purpose of this regulation is to protect customers who are engaged in those types of services. Regulation E had highlighted different type of electronic fund transfer for instance, remittances, overdrafts, direct deposits, ATMs and telephone transfers.

There are three main types of remittances offered by the dual bank (Bank A): express service, card payment, and telegraphic transfer. The express service allows customers to transfer money worldwide through correspondent and beneficiary banks. The receivers can either receive in cash or credit, within two working days. However, the credit transfer is limited to certain countries due to legal or regulatory restraints.

The card payment, on the other hand, allows customers of Bank A to transfer their money abroad via debit card and credit card. There are daily and monthly transfer limits for using card payment service. The daily limit range from RM 300 to RM 7,500 whereas the monthly limit is up to RM 50,000 or 8 transactions per calendar month. Customer of Bank A can choose to transfer money in two working days or within half an hour. As in credit transfer, customer from Bank A cannot transfer money to certain countries via card payment.

Lastly, telegraphic transfer is a mean to transfer money either by cash or credit to overseas accounts where the amount will be directly debited from the account. The daily limit for telegraphic transfer ranges from RM 250 to RM 30,000.

\section{Practices in Malaysian Banks:}

As per the findings, The dual bank (Bank A) remittance practices allow customers to transfer funds globally by fulfilling the following requirements; (i) maximum daily transaction limit, (ii) specify the purpose of transfer of any sum above RM5000.50/-. The processing remittance is done via SWIFT; however, the actual time taking will depend on the respective agent or recipient's Bank.

International Journal of Management and Applied Research, 2016, Vol. 3, No. 3 
However, the solely Islamic bank (Bank B) does offer foreign telegraphic transfer and started to provide remittance business services for walk-in customers (non-account holders) since 2009.

\section{Documentation:}

Both Bank A and B have the same requirements with regards to identification of clients and record keeping. The source of funds must be specified if the transaction amount is considerably huge. Banks are required to obtain detailed information for both applicant and the beneficiary, including identity card, address of residence, employment record, etc. Additionally, the purpose of payment (services or goods, capital or special transactions and BNM approval reference number if applicable) must be specified. Table 2 illustrates the documents required for remittances by both Bank $\mathrm{A}$ and $\mathrm{B}$.

Table 2: Documents Required

\begin{tabular}{|l|}
\hline \multicolumn{1}{|c|}{ Full Applicant } \\
Details
\end{tabular}

\begin{tabular}{|l|}
\hline \multicolumn{1}{|c|}{$\begin{array}{c}\text { Beneficiary } \\
\text { Details }\end{array}$} \\
\hline * Name \\
- ID or Passpont \\
- Number \\
- Resident or \\
- Don-resident \\
- Country \\
- Full Address \\
includes \\
telephone \\
number \\
\end{tabular}
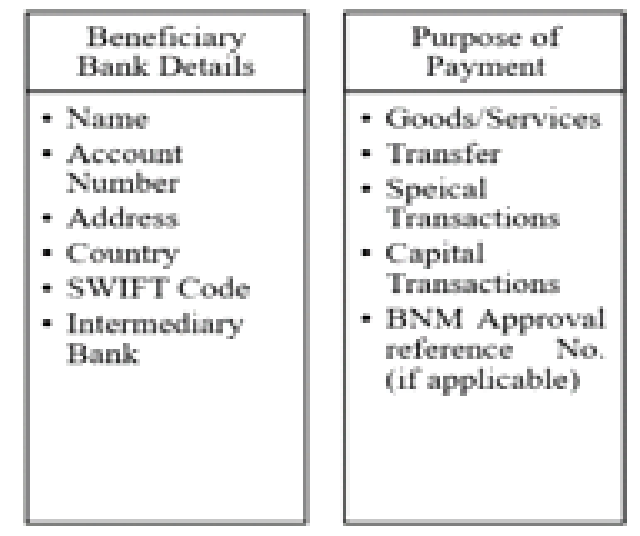

\subsection{Travellers' Cheques}

Travellers' cheques are negotiable instruments which customers can purchase and use while travelling. These type of cheques were used to replace cash and more favourable when ATMs were not in exist. It is exchangeable with any Bank or money changer globally but it requires personal presence and signature.

\section{Practices in Malaysian Banks:}

Bank A confirmed that travellers' cheque has been discontinued from its operations. Bank B, on the other hand, do not offer travellers' cheques to its customers.

\section{Documentation:}

Both Bank A and B have stopped issuance of travellers' cheques and they encourage the use of money gram (remittance) and ATM cards. Since the service of travellers' cheques has been discontinued, no documents are available.

\subsection{Cheques}

Cheque is a documentary form which gives authorization to the Bank to pay a certain amount to a specific person who the cheque was issued to. Generally, in order to obtain cheque books, customers must be a current account holder. Cheques must be 
issued only to such an amount that would be less than or at most equal to what is available in the current account.

\section{Practices in Malaysian Banks:}

As per the new regulations published by Central Bank of Malaysia (BNM) on 19th March 2014, in respect of pricing for cheques (Ref No. 03/14/07), BNM increased cheque processing fees by RM. 0.050 in order to limit the usage of paper based instruments and to encourage to use e-payment services. Regardless of any Bank, all cheques will be channelled to clearing house which is controlled by BNM. However, the duration may differ from Bank to Bank. The duration of cheque clearance is shorter in the dual bank compared to solely Islamic bank. There is a difference of one or two days between the dual bank and solely Islamic bank. The table illustrates the duration of cheque clearing (see Table 3 ).

Table 3: Duration of Cheque Clearance

\begin{tabular}{lcc}
\hline Type of cheque clearing & The Dual Bank (Bank A) & Solely Islamic Bank (Bank B) \\
\hline bank to bank (same branch) & One day & Two days \\
bank to bank (other branch) & Three days & Three days \\
bank to different banks & Three days & Three days
\end{tabular}

In respect of the solely Islamic Bank, it limits the usage of cheques to comply with $\mathrm{BNM}$ regulations in limiting the usage of paper cheques.

Documentation: The table 4 illustrates the documents required by the two Banks in order to open current accounts to have cheque book. Based on the interview, it was found that generally students are not eligible to open current account in order to minimise the risk of issuing cheque without sufficient fund and to avoid bounced cheques. However, students may apply online or through private banking with high net-worth.

Table 4: Documents Required to Open Current Account

\begin{tabular}{|c|c|c|}
\hline The dual bank Conventional & The dual bank Islamic & Solely Islamic bank \\
\hline Optional identity card for & Optional identity card for & Optional identity card for \\
\hline Malaysians & Malaysians & Malaysians \\
\hline Passport for foreigners & Passport for foreigners & Passport for foreigners \\
\hline $\begin{array}{l}\text { Valid working visa or student } \\
\text { permit }\end{array}$ & Utility bills & Full details of the applicant \\
\hline $\begin{array}{l}\text { Letter of confirmation from } \\
\text { employer or education } \\
\text { institution }\end{array}$ & Letter of employment & Employment information \\
\hline
\end{tabular}

International Journal of Management and Applied Research, 2016, Vol. 3, No. 3 


\section{Recommendation and Conclusion}

The interviews and other information obtained indicate that there is no awareness of the underlying Sharíah principle for these transactions. The Islamic banks simply accept that these transactions are Sharī'ah compliant. Furthermore, no significant differences were found with regards to the operational aspects of these three hawālahbased transactions between the conventional and the Islamic banks.

This paper highlights that hawālah is a Sharī'ah principle that is commonly used in banking sector. Nonetheless, the misuses (van de Bunt, H. (2008; Shanmugam, 2005; Wilson, 2002) or perhaps abuses of the concept overshadow its legitimate uses. This paper explores the modern applications of hawālah in the areas of personal financing such as money remittance, cheque clearing and traveller's cheques. The authors interviewed members of staffs from two Malaysian banks and the results showed that there is general low awareness of the hawālah concept. For that reason, it is recommended here that bank personnel, especially those who are involved in Islamic banking, should have an in-depth understanding on the Shariah compliant products, including ḥawālah.

This study has a few research limitations. The first is its small sample due to the exploratory nature of this study and thus the final result do not represent the population in the Malaysia banking sector. Future research could perhaps increase the number of banks or compare the hawālah operations in different countries. Secondly, this study has a narrow focus on personal finance and thus the use of hawālah in other banking services such as international finance and trade are not examined. The forthcoming research could scrutinise the employees' attitudes and awareness towards hawālah, in the context of international trade.

\section{References}

1. Auditing and Governance Standards for Islamic Financial Institutions (AAOIFI) (2010) Shariah Standard.

2. Al-Zuhayli, W. (2003), Islamic Jurisprudence and Its Proofs, Dar al-Fikr, 33.

3. El Qorchi, M., Maimbo, S. M., and Wilson, J. F. (2003), Informal Funds Transfer Systems: An analysis of the informal hawala system, Occasional Paper 222, International Monetary Fund [Online] available from: http://www.imf.org/external/pubs/nft/op/222/ [Accessed on 5 July 2016].

4. Hernandez-Coss, R. and Bun, C. E. (2007), The UK-Nigeria remittance corridor: challenges of embracing formal transfer systems in a dual financial environment, World Bank, [Online] available from:

https://www.cbd.int/financial/charity/nigeria-remittance.pdf [Accessed on 1 June 2016].

5. International Shari'ah Research Academy for Islamic Finance (ISRA) (2012), Islamic Financial System - Principles \& Operations, Kuala Lumpur: ISRA.

International Journal of Management and Applied Research, 2016, Vol. 3, No. 3 
6. Jost, P. M. and Sandhu, H. S. (2000), The hawala alternative remittance system and its role in money laundering, USA: Treasury Financial Crimes Enforcement Network, [Online] available from: https://www.treasury.gov/resourcecenter/terrorist-illicit-finance/Documents/FinCEN-Hawala-rpt.pdf [Accessed on 15 June 2016].

7. Kasri, R. And Kartika Dewi, M. (2011), "SMEs Financing Innovation: Application of Hawalah in Islamic Cooperative", International Journal of Excellence in Islamic Banking and Finance, Vol. 1, No. 2, pp. 1-15.

8. Kureshi, H. and Hayat, M. (2014), Contracts and Deals in Islamic Finance: A User?s Guide to Cash Flows, Balance Sheets, and Capital Structures, Singapore: John Wiley \& Sons.

9. Maimbo, S. M. (2003), The Money Exchange Dealers of Kabul: a study of the Hawala system in Afghanistan, USA: World Bank Publications.

10. Nelson, D. (2009), "Hawala King Naresh Jain arrested in India", The Telegraph. [Online] available from: http://www.telegraph.co.uk/news/worldnews/asia/india/6753574/Hawala-KingNaresh-Jain-arrested-in-India.html [Accessed on 1 July 2016].

11. Niazi, L. A. K. (1991), Islamic Law of Contract, Research Cell, Dayal Singh Trust Library.

12. Passas, N. (1999), Informal Value Transfer Systems and Criminal Organizations; A Study into So-Called Underground Banking Networks. [Online] available from: http://papers.ssrn.com/sol3/Delivery.cfm/SSRN_ID1327756_code1190259.pdf?abs tractid=1327756\&mirid=1 [Accessed on 1 July 2016].

13. Shanmugam, B. (2005), "Hawala and money laundering: a Malaysian perspective", Journal of Money Laundering Control, Vol. 8, No. 1, pp. 37 - 47. https://doi.org/10.1108/13685200510621181

14. Shehu, A. Y. (2004), "The Asian alternative remittance systems and money laundering", Journal of Money Laundering Control, Vol. 7, No. 2, pp.175 - 185 https://doi.org/10.1108/13685200410809896

15. Siegel, M., Vanore, M., Lucas, R., and de Neubourg, C. (2010), The NetherlandsAfghanistan Remittance Corridor Study: A report commissioned by the Dutch Ministry of Foreign Affairs, World Bank [Online] available from: http://siteresources.worldbank.org/FINANCIALSECTOR/Resources/2820441241752859230/The_Netherlands_Afghanistan_Remittance_Corridor_Study_2010 .pdf [Accessed on 11 July 2016].

16. Todoroki, E., Celik, K., and Kholmatov, M. (2011), Alternative remittance systems in Kazakhstan, World Bank [Online] available from:

http://siteresources.worldbank.org/FINANCIALSECTOR/Resources/ARSJuly2012(English).pdf [Accessed on 11 July 2016].

17. Wilson, J. F. (2002), Hawala and other informal payments systems: an economic perspective. International Monetary Fund [Online] available from: https://www.imf.org/external/np/leg/sem/2002/cdmfl/eng/wilson.pdf [Accessed on 2 July 2016].

International Journal of Management and Applied Research, 2016, Vol. 3, No. 3 
18. van de Bunt, H. (2008), "A case study on the misuse of hawala banking", International Journal of Social Economics, Vol. 35, No. 9, pp.691 - 702. https://doi.org/10.1108/03068290810896316

19. Viles, T. (2008), "Hawala, hysteria and hegemony", Journal of Money Laundering Control, Vol. 11, No. 1, pp.25 - 33. https://doi.org/10.1108/13685200810844479 